\title{
Commentary
}

\section{Back to the Future: Not looking into the Future but at Futures}

\author{
Key note at the $7^{\text {th }}$ Nordic Working Life Conference, Threats and \\ Possibilities Facing Nordic Working Life in Gothenburg, Sweden, June \\ II-13, 2014
}

\section{Ann Bergman}

Associate Professor in Working Life Science at Karlstad University Business School, Sweden ${ }^{1}$

T

his speech is about the trickiness of the future. Thus, I will share my thoughts about why I think it is important for researchers interested in work-life matters to engage in a discussion about the future. I would like to stress the importance of engaging in discussions about the future, since the purpose of my talk is not to encourage work-life researchers to collectively convert into oracles, prophets, or fortune-tellers.

In this way, this talk is a sort of reasoning out loud about the future, or futures. However, I will not look into the future, making claims such as whether we will experience an increased formalization of work, the formalization thesis, or, instead, if there is an informalization of work and welfare to expect (Beck 1992, Gorz 1999, Handy 1984, Rifkin 1995). I will not argue that the future will take place according to the growth of capitalism and commodification thesis, or if it is de-commodification of employment and work that increases (i.e., post-capitalist or non-capitalist visions of work). Similarly, I will not reveal whether it is the globalization thesis, emphasizing an open global deregulated market, or the localization of work and welfare thesis that we will experience in the future.

Besides these claims, there are a number of questions that I will not answer. For example: Is Rifkin right about a third industrial revolution? Will the boundaries between work, leisure, and family be diminished? Will the work force be feminized? Will Fordism continue to exist? Will there be more control in tomorrow's working life, or less? Will the computers that recently have fooled experts that they are human be a part of future management?

Instead of looking into the future I will look at the future; that is, the phenomenon (Adam and Groves 2007). I also want to mention that the perspectives that I will use, and my own standpoint in this talk, is as a social scientist and is ethnocentric in a global perspective.

My talk has the following structure: I will start by arguing why I believe the future is important. I will then continue with a note on the absence of futures studies in

\footnotetext{
${ }^{1}$ Ann Bergman, Working Life Science, Business School, Karlstad University, 65188 Karlstad, Sweden; Phone +4654700 15 24. E-mail: Ann.Bergman@kau.se
} 
working life-related journals, and the absence of work-life matters in future studies. I will describe some of the ways in which research has formulated knowledge about the future. The talk will be finished by returning to why I think working life research needs to engage in the future.

\section{Why is the future important?}

Why do I think the future is important? Well, because, as Barbara Adams and Chris Groves put it, quite succinctly: It matters! The future is not only imagined (Adam and Groves 2007: xiii); it is also made and created all the time, everywhere. This is done in our everyday practice at work and elsewhere, through policies and politics, through technology and medicine, and through education and science-such as in science related to work life.

One of the most famous futurists, Wendell Bell (2003), argues that we are all time travelers, holding a one-way ticket to the future since there is no ticket going back. This might sound like something from a science fiction movie and rather fatalistic, but the important point is that we are agents creating the future and that we, including us researchers, are therefore morally responsible for the "not yet" (Adam 2008: 111-112).

In order to understand agency, one can distinguish between two orientations in relation to the future. One is being oriented toward the future; that is from the present and forward. The other is guided by the future; that is, its time orientation is the opposite, backward from the future toward the present (Adam and Groves 2007). No one can put themselves outside this time orientation. These thoughts are not new; in Philosophy of the present, for example, Herbert Mead ([1932] 2002) stated that all our actions are a result of the past, the present, and the future and that actions are future-oriented. So, not only the past and the present are conditioning social activity-but also the future. In other words, I would like to argue that the future is real since it is causal and it makes things happen in the present.

Claims made about the future in a competitive society, such as ours, are often filled with positive connotations about the future, since it is an extended arena for the present competition. Corporations and other organizations often stress the importance of being first, at the front line. We have to be prepared to meet the future and be one of the first entering into it. It seems like there is a belief that someone can be ahead of someone else into the future. Future orientation goes hand-in-hand with visions, plans, goals, and achievements-things that are valued in our society. Consequently, the future-the not yet-is seen as a resource for some and a threat to others.

The future and statements about the future can sometimes be used to influence and impinge upon the behavior of individuals and collectives. Here, one can use the future as a dystopian warning lamp in order to try to avoid certain things happening by trying to guide how people and organizations act. An example is the environmental movement, where research, politics, media, and popular culture often use the future to depict a worst-case scenario in order to change how people and organizations behave regarding sustainability.

Other examples are trade union warnings about the increase of bad working conditions or levels of unemployment. The same warning system can be used by researchers as 
well. Examples include Thomas Piketty's (2014) warning about the uneven distribution of wealth in society, or Guy Standings' (2011) warning of a growing precariat.

We can also use the future as a way to try to achieve desired outcomes and talk about best-case scenarios, or even about utopias. The goals and visions of organizations are desired scenarios in the near or distant future, and the same applies to politicians' ideological views. Another example is the feminist vision of a gender-equal society.

The future is a contemporary social condition for our actions at the same time as we are creating it (Adam 2008: 113). This means that we, as researchers, are a part of this creation process, whether we want to be or not. Even more importantly-since we are a part of it-we can also be held responsible for the future: the coming present. In other words, we are responsible for things that have not yet happened.

Moreover, since this conference is about The threats and possibilities facing Nordic working life, I want to emphasize that all of the relevant ingredients for a discussion about the future are in the title.

The word facing is future-oriented. Also, the terms threats and possibilities point toward the 'not yet' and show that things can take different directions, which are more or less preferable. I think that the title of this conference-like those of so many other conferences-should be considered more seriously and taken as a call for action. Working life researchers need to be involved in discussions about future work and society. This is not really the case at present.

\section{The absence of work in future studies and the absence of futures in work-life studies}

When it comes to working life matters, one can say that the combination of future studies and working life research is not very common. My colleagues and I conducted a research project together with the purpose of studying predictions about working life in literature in the work-life field. ${ }^{1}$ We did not find many. Of course, there are a number of quite well-known writings, often criticized-including those by Toffler, Rifkin, Handy, Gorz, Drucker, and Castells-that are more or less about work and the future, but more often has a broader societal focus.

As a whole, however, working life researchers tend to be reluctant to conduct futures studies or deal with the future as such. Alternatively, some might be interested but not get published in journals such as Work, Employment and Society or Gender, Work and Occupation. The same applies to Arbetsmarknad \& Arbetsliv and Nordic Journal of Working Life Studies as well.

However, the lack of interest seems mutual. Today's futurists in academia rarely write about working life matters. Since 1995, only about 2 percent of the articles in Futures, the most well-known journal that takes a social or a behavioral science approach, deal with work-life matters. Especially absent are articles about working conditions.

Studies of and claims about the future tend to be carried out by futurologists outside the academia, and be taken up by actors related to business or to politics and policymaking. There are for example small-scale consultants, advisors, experts, or think tanks and their focus is often on innovation and/or growth. I regard this as a problem. 


\section{So how do we study the future?}

Despite what I have just said, some scholars do conduct future studies and I now intend to provide a brief sketch about the different types and logics behind various forms of future studies. From a historical perspective, the future has been looked into by various experts who have claimed to have a direct channel into it, such as prophets, oracles, witches, druids, priests, fortune-tellers, and astrologers (Adam and Groves 2007: 2-3). In many of these historical ways of understanding the future, the lesson is you cannot escape your fate even if you know it. It is a deterministic way of looking at the future. Today, we may ridicule the use of tools such as cards, bird bones, or the contents of a dead fish's stomach to say something about the future. Nonetheless, we still rely on tools such as advanced statistical modeling and trend analysis for essentially the same purpose; that is, to try and control the future and to make it less threatening and uncertain.

Examples of methods that rely on the logic of past-based causality and continuity are prediction, prognosis, forecast, and trend analysis-all of which are calculations and claims about the future, whether they are cyclical or linear. Here, accumulated facts about the past and the present give us an idea of what is next. This rather mechanistic way of understanding society, which relies on calculations and estimations of repetition and continuity, is strong in the Western world. Facts and their operational domain are the past and the present, and these facts are often presented as evidence for the future as well. The problem that these types of methods face is that, in a social context, there is not only continuity but also variation; in some cases the variation is so great that one can't talk about continuity at all. Moreover, as you might have experienced yourself, we tend to find continuity where we expect discontinuity, and discontinuity where we expect continuity.

I will give you two examples. The first is Göran Therborn and Joop Roebroek's (1986: 332) article entitled The Irreversible Welfare State, which states, "the welfare state is an irreversible major institution of advanced capitalist countries, as long as democracy prevails. The building of a majoritarian anti-welfare state coalition seems impossible for the foreseeable future." Today, we are all witnessing what is happening to the welfare state in our Nordic countries.

The second example is a more recent one from the celebrated Piketty (2014: 27), who has stated "the process by which wealth is accumulated and distributed contains powerful forces pushing toward divergence, or at any rate toward an extremely high level of inequality." This makes sense, but, if we start to act against it we might be able to reverse it. This is something that the example of the welfare state prediction above just proved possible.

Here I would like to share some insights from an early futurologist, Bertrand de Jouvenel (1967: 5), who argued that knowledge about the future is a contradiction in itself. This is because at the same time as you state something about the future, you might alter it one way or another, and conditions and interdependencies will affect the predicted outcome. The more socially interconnected the forecast and/or the activity, the harder it is to predict (Adam and Groves 2007: 30-31). De Jouvenel continues that "our knowledge of the future is inversely proportional to the rate of progress" (1967: 275). In other words, in a society that has a great capacity to produce innovation and change, one should be wary on relying solely on evidence-based knowledge since it is based on 
past facts in order to gain knowledge about future consequences and is best suited in stable contexts (Adam and Groves 2007).

As an alternative way of dealing with the future, futurologists argue-in line with de Jouvenel and Bell, among others-that there are no future facts, only future possibilities (i.e., futuribles). These futurologists use methods such as scenario planning, foresight, back casting, weak signals scanning, horizon scanning, and Delphy methods. These methods also rest upon past- and present-based knowledge about what is likely to happen, but also on conjecture about what could happen and visions about what is desirable or preferable; in other words, what do we want and how do we get there? These techniques regard the future as empty and open, ready to be filled with content. Even though the past and the present are conditioning, the future is subject to human intervention and is therefore ours to make.

For example, there is an ongoing research project based at the Royal Institute of Technology in Stockholm called Beyond BNP growth: Scenarios for a sustainable development and community building. The purpose is to prepare the future society for a declining growth by generating knowledge from three different growth scenarios. Another project has been conducted in the area of work-life science at Luleå Technological University called the Future Factory. This project focuses on what good work has been, is, and can be in the future, as defined by women and young people-a category that is frequently not in a position to define production systems in a male-dominated context. Another international example is the Real Utopias Project, which started in the United States in 1991. That project focuses on what the researchers see as a preferable future by exploring various theories and models for social change, driven by the idea of emancipatory agency.

As I have tried to show, there are different ways of approaching the future. One is oriented from the past and looks forward, while the other is oriented from the future and looks backward. As I see it, both of these time horizons are necessary when understanding the future, since it is always in the making and in between the past, the present, and the not yet manifested. I fully agree with Adam and Groves (2007: 37) that the future is not an empty territory, a tabula rasa waiting to be filled, but is instead occupied by visions, plans, decision, and actions-in the process of being materialized into empirically accessible facts.

\section{Implications for working life science}

Why is it so important that working life researchers be involved in the future developed? Well, as I said at the start of this talk, visions about the future tend to be made by influential vested interests (Williams 2007: 288). Powerful groups, stakeholders, organizations, and institutions try to make the future predictable and controllable through promises, obligations, contracts, laws, or other ways of managing things in their desired direction. Looking at today's work life, one can conclude that future-oriented emancipatory actors are missing from work-life research. As a point of reference, imagine a society without the knowledge and emancipation of yesterday's feminist scholars. What was their future is the present for us.

Therefore, I also think that working life researchers need to pay attention to and engage in the future as a potential subject for moral and normative intervention. In other 
words, we can make a better work life and society through our knowledge and reason. Otherwise, there is a risk that our work life might continue to be strongly influenced by economic and political interests that do not hesitate to articulate statements about the future as if they were true.

So, I would like to stress the value of emancipatory agency and the possibility for us to be part of the restructuring of working life and social institutions in accordance with values that we share, such as equality, good working conditions, or other aspects that are being identified and discussed at our conference. If we, as researchers, do not dare to take action, and instead regard the future as "decontextualized and depersonalized," it can be used and abused, by others, without us feeling guilt, remorse, or responsibility. That is problematic since our future is the present of others (Adam and Groves 2007: 13).

Many of us are doing this in various ways already, but I believe we need to be more explicit about it and actually talk about the future-both inside and outside academiawith our knowledge about working life as a point of departure.

\section{References}

Adam, B. (2008) Future matters: futures known, created and minded. Twenty-First Century Society, 3(2), 111-116.

Adam, B. \& Groves, C. (2007) Future matters: action, knowledge, ethics. Leiden: Brill.

Beck, U. (1992) Risk society: towards a new modernity. London: Sage.

Bell, W. (2003) Foundations of futures studies: human science for a new era. vol. 1, History, purposes, and knowledge. New Brunswick, NJ: Transaction Publishers.

Gorz, A. (1999) Reclaiming work: beyond the wage-based society. Cambridge: Polity Press.

Handy, C. (1984) The future of work: a guide to a changing society. Oxford: Blackwell.

Jouvenel, B.D. (1967) The art of conjecture. New York: Basic Books.

Mead, G.H. (2002[1932]) The philosophy of the present. Amherst, NY: Prometheus Books.

Piketty, T. (2014) Capital in the twenty-first century. Cambridge, MA: Belknap Press of Harvard University Press.

Rifkin, J. (1995). The end of work: the decline of the global labor force and the dawn of the post-market era. New York: G.P. Putnam's Sons.

Standings, G., (2011) The precariat: the new dangerous class. London: Bloomsbury Academic

Therborn, G., \& Roebroek, J. (1986) The irreversible welfare state: its recent maturation, its encounter with the economic crisis, and its future prospects. International Journal of Health Services, 16(3), 319-338.

Williams, C.C. (2007) Rethinking the future of work: directions and visions. Basingstoke: Palgrave Macmillan.

\section{End notes}

1 "The Future of Work - Yesterday and Today. An Empirical and Theoretical Study of Predictions". Riksbankens Jubileumsfond. 